УДК 37.01-053.8

DOI 10.31654/2663-4302-2020-PP-27-39

\title{
Borisyuk I.
}

podyplomowy Katedry Pedagogiki Społecznej i Pracy Socjalnej,

Niżyński Państwowy Uniwersytet im. M. Gogola, Ukraina

\begin{abstract}
Novgorodska J.
кandydat nauk pedagogicznych, profesor nadzwyczajny Katedry Pedagogiki. Edukacji Podstawowej i Zarządzania Oświatą, Niżyński Państwowy Uniwersytet im. M. Gogola, Ukraina
\end{abstract}

\section{Szala A.}

student studiów podyplomowych przygotowania pedagogicznego,

Państwowa Wyższa Szkoła Zawodowa w Chełmie, Polska

\section{SYSTEM WARTOŚCI KSZTAŁCĄCYCH SIĘ OSÓB DOROSŁYCH}

Artykuł aktualizuje problematykę tworzenia systemu wartości jako aksjologicznej podstawy człowieka. Określona zostaje istota zjawiska "wartości"; ujawniono główne stanowiska naukowe naukowców krajowych i zagranicznych na temat badanego zjawiska. Dokonano analizy terminologii podanej w literaturze naukowej na ten temat. Przeanalizowano hierarchię wartości końcowych i instrumentalnych współczesnego człowieka.

Autorzy opisują czynniki wpływające na kształtowanie wartości życiowych. Przeanalizowano wpływ płci na kształtowanie się ich systemu wartości. Analiza porównawcza systemu wartości uczących się przedstawicieli różnych płci oraz kobiet i mężczyzn nie zajmujących się edukacją.

Badane są różnice $w$ preferencjach wartości między mężczyznami i kobietami, którzy otrzymują wykształcenie, a nieuczącymi się przedstawicielami różnych płci. Zbadano różnice płci w preferencjach wartości między kobietami (mężczyznami), które otrzymują wykształcenie, a tymi, które go nie otrzymują.

Słowa kluczowe: wartości, orientacje wartości, hierarchia wartości, osobowość, płeć, różnica płci.

Sformułowanie problemu. System wartości, jak podaje W. Ignatczyk, zazwyczaj rozumiany jest jako system kategorii poznawczych człowieka, które służą mu do opisu oraz oceny świata i stanowi także podstawę dokonywanych przez niego wyborów pomiędzy liczbą pewnych stanów docelowych. Systemy te nie stanowią uniwersalnej kategorii, ponieważ nie dla wszystkich grup społecznych czy każdego człowieka określone cele mają taką samą ważność. Określony system wartości w znacznym stopniu kształtuje się pod wpływem zindywidualizowanych potrzeb oraz postaw jednostki, a także jej aspiracji [6, s. 133]. System wartości stanowi również istotny składnik kultury, w jakiej żyje człowiek [8, s. 261].

Próba opisu systemu wartości danego człowieka lub grupy społecznej czy całej zbiorowości, jak podkreśla S. Nowak, skupia się na dwóch głównych aspektach tego systemu wartości. Są to przekonania oraz odczucia ludzkie, które określane są mianem "wartości" [8, s. 261]. W literaturze aksjologicznej istnieje bogactwo definicji słowa "wartość" [3, s. 17-19]. Istnienie bogactwa definicyjnego tego terminu świadczy o jego wielowymiarowości oraz wieloznaczności i możliwości jego różnej interpretacji [4, s. 15]. W Encyklopedii Aksjologii Pedagogicznej odnajdujemy definicję wartości wyjaśniającą, że wartość to "podstawowa kategoria aksjologii (...), odnosząca się do tego, co cenne, godne posiadania, ważne, użyteczne, stanowiące cel ludzkich dążeń" [9, s. 1304]. Zgodnie z tą definicją oraz definicją "wartości" zaproponowaną przez M. Łobockiego wyjaśniającą, że wartością jest "to co jest cenne i ważne dla danej jednostki i społeczeństwa, jest godne pożądania i łączy się z pozytywnymi przeżyciami, co stanowi cel ludzkich dążeń" [7, s. 55], podobnie będzie rozpatrywany system wartości człowieka. S. Nowak stwierdza, że rozpatrując system wartości człowieka dokonuje się próby określenia tego, co jest dla 
człowieka "bardziej lub mniej ważne - jakie przedmioty, sfery życia czy obszary rzeczywistości ich otaczającej koncentrują na sobie ich uwagę, wyzwalają emocje i oceny, wytwarzają poczucie identyfikacji czy zaangażowania" [8, s. 261].

Człowiek jako jednostka stanowi wraz z wartościami integralną całość; przyjmuje względem nich postawę wyboru bądź odrzucenia [1, s. 177]. Wartości stanowią nieodłączny element życia ludzkiego. Pełnią w jego życiu ważne funkcje. Wpływają na proces kształtowania charakteru jednostki, jak i całych społeczeństw [5, s.38]. Wartości w decydujący sposób wpływają na jakość życia ludzkiego, nadając mu jednocześnie kierunek [10, s. 158]. Pobudzają aktywność człowieka oraz motywują go i inspirują. Wartości stanowią również czynnik podmiotowości oraz autonomii człowieka [5, s. 39]. Przyczyniają się do integralnego rozwoju człowieka oraz budzą jego świadomość, wzmacniają jego wolę, a także dynamizują myślenie. Wartości budują życie duchowe człowieka i budzą świadomość własnego istnienia, a także pomagają w rozwiązywaniu konfliktów [1, s. 178].

W procesie edukacji wartości występują jako system norm, które rzutują na działania nauczycieli oraz uczniów. Podczas procesu kształcenia następuje odwołanie do wartości, z którymi uczniowie powinni się identyfikować. W procesie edukacji należy dążyć do tego, by wartości były rozpoznawane, rozumiane, akceptowane oraz respektowane. Proces kształcenia to proces kreowania ciągów poznawczych i zrozumiałych sytuacji aksjologicznych, w których uczeń ma możliwość poznania, zrozumienia i przyjęcia (bądź odrzucenia) danej wartości. Dzięki temu uczeń tworzy hierarchiczny system wartości [3, s. 29].

Pomimo tego, że życie społeczne człowieka zmienia się do późnego wieku, a każda kolejna rola społeczna wnosi nowe doświadczenia i rozwija nowe dążności, to jak twierdzi F. Znaniecki, "to te dążności społeczne rozwinięte w pierwszym okresie życia nadają główny kierunek tej ewolucji" [11, s. 115]. Pomimo tego, że świat wartości ma przede wszystkim istotne znaczenie, zwłaszcza dla ludzi młodych dopiero kształtujących swoją osobowość, jest również ważny dla człowieka w każdym wieku [2, s. 133].

Celem artykułu oraz przeprowadzonych badań własnych jest poznanie wartości preferowanych przez osoby dorosłe, które podejmują kształcenie. Główny problem badawczy przeprowadzonych badań zawierał się w pytaniu: Jaki jest kształt hierarchii wartości osób dorosłych, które się kształcą? W ramach przeprowadzonych badań przeanalizowano również wpływ płci badanych na kształt ich systemu wartości oraz dokonano analizy porównawczej systemu wartości kobiet i mężczyzn, którzy się kształcą, a także kobiet i mężczyzn niepodejmujących kształcenia.

Przedstawianie materiału głównego. Badania zostały przeprowadzone w listopadzie 2019 roku. Badaniami zostali objęci słuchacze jednej ze szkół policealnych. Jest to Szkoła Policealna Centrum Nauki i Biznesu "ŻAK" w Chełmie. Szkoła ta jest jedną z największych sieci tego typu szkół w kraju, kształcąca osoby dorosłe na wielu kierunkach. W badaniu wzięły również udział losowo wybrane osoby dorosłe, obecnie nie kształcące się i nie planujące podjęcia nauki w przyszłości. Stanowiły one w prowadzonych badaniach grupę porównawczą.

Uczestnikami badań byli słuchacze kierunku florystyka i technik turystyki wiejskiej oraz losowo wybrane osoby dorosłe, które się nie kształcą (grupa kontrolna). Łącznie przebadano 98 osób (36 mężczyzn oraz 62 kobiety). Osoby badane zostały podzielone na dwie główne grupy badawcze: pierwszą stanowiło 51 osób dorosłych uczących się, a drugą 47 osób dorosłych, które nie podejmują nauki oraz na potrzeby prowadzonych analiz, wyżej wymienione grupy badawcze podzielono pod kątem płci badanych. Ze względu na specyfikę jednego z kierunków kształcenia, na którym przeprowadzano badania (florysta) wśród grupy osób uczących się liczba kobiet była dwukrotnie większa niż mężczyzn (34 kobiety oraz 17 mężczyzn). Wiek osób, które brały udział w badaniach oscylował w granicach $19-69$ lat.

Udział w badaniu był dobrowolny i anonimowy. Badani zostali poproszeni o wybór 10 najważniejszych dla nich wartości spośród 40, znajdujących się w zastosowanym w badaniach katalogu. Każda z 40 zaprezentowanych w narzędziu badawczym wartości została uszczegółowiona krótkim opisem, np.: miłość (miłość do drugiego człowieka, dawanie i doświadczanie miłości, miłość bliźniego), rodzina (założenie rodziny, szczęście 
rodzinne, dobre wychowanie dzieci), zdrowie (sprawność fizyczna i umysłowa, korzystny wygląd, sport, zdrowe środowisko), praca zawodowa (praca w zawodzie, mieć dobrą pracę, zadowolenie z pracy), wiedza (zdobywanie, gromadzenie i posiadanie wiedzy, erudycja), własny rozwój (poznanie i rozwijanie swych zdolności, realizowanie swych możliwości). Po wyborze 10 najważniejszych w ich życiu wartości, badani musieli uszeregować je od najważniejszej do najmniej cenionej. Na podstawie wyborów wartości dokonywanych przez badanych z katalogu zawierającego nazwy 40 wartości stworzono hierarchię najbardziej cenionych wartości przez osoby dorosłe, które brały udział w badaniach.

Wyniki badań własnych $\mathbf{i}$ ich omówienie. W pierwszej kolejności były rozpatrywane wartości preferowane przez osoby kształcące się. $\mathrm{Na}$ podstawie dokonywanych przez nie wyborów konkretnych wartości stworzono hierarchie wartości tej grupy osób, która została przedstawiona w tabeli 1.

Jak wynika $z$ danych zaprezentowanych w tabeli 1, najbardziej cenioną wartością dla osób dorosłych kształcących się jest zdrowie. Tak deklarowało 68,63 \% badanych. $\mathrm{Na}$ szczycie hierarchii wartości preferowanych tych osób znalazły się również takie wartości jak: rodzina $(64,71 \%)$, miłość $(62,75 \%)$, szacunek $(50,98 \%)$ oraz wiedza $(49,02 \%)$. Badani wysoko cenią również własny rozwój $(47,06 \%)$ oraz mądrość $(41,18 \%)$. Osoby kształcące się, które brały udział w badaniu, również wysoko umiejscawiają w hierarchii zainteresowania oraz wykształcenie. Tak deklaruje odpowiednio $37,25 \%$ i 33,33\% badanych. Najmniej cenionymi wartościami w życiu badanych, którzy się kształcą są: spryt życiowy $(5,88 \%)$, wygodne życie $(5,88 \%)$, pozycja społeczna $(1,96 \%)$ oraz władza $(1,96 \%)$.

Tabela 1

Hierarchia wartości preferowanych przez osoby dorosłe kształcące się

\begin{tabular}{|l|c|c|}
\hline \multirow{2}{*}{\multicolumn{1}{|c|}{ Wartość }} & \multicolumn{2}{|c|}{$\mathbf{N}=\mathbf{5 1}$} \\
\cline { 2 - 3 } & $\mathbf{n}$ & $\%$ \\
\hline Zdrowie & 35 & 68,63 \\
\hline Rodzina & 33 & 64,71 \\
\hline Miłość & 32 & 62,75 \\
\hline Szacunek & 26 & 50,98 \\
\hline Wiedza & 25 & 49,02 \\
\hline Własny rozwój & 24 & 47,06 \\
\hline Mądrość & 21 & 41,18 \\
\hline Pomoc innym ludziom & 19 & 37,25 \\
\hline Zainteresowania & 19 & 37,25 \\
\hline Wykształcenie & 17 & 33,33 \\
\hline Godność osobowa & 17 & 33,33 \\
\hline Prawda & 16 & 31,37 \\
\hline Szczęście osobiste & 16 & 31,37 \\
\hline Praca zawodowa & 16 & 31,37 \\
\hline Dobro moralne & 16 & 31,37 \\
\hline Umiejętność współżycia z ludźmi & 16 & 31,37 \\
\hline Przyjaźń & 15 & 29,41 \\
\hline Wiara w Boga & 13 & 25,49 \\
\hline Sprawiedliwość & 13 & 25,49 \\
\hline Pokój & 12 & 23,53 \\
\hline Zabezpieczenie bytu & 12 & 23,53 \\
\hline Kształtowanie charakteru & 12 & 23,53 \\
\hline Radość życia & 11 & 21,57 \\
\hline Samodzielność & 10 & 19,61 \\
\hline Kontakt z przyrodą & 10 & 19,61 \\
\hline Życie towarzyskie & 9 & 17,65 \\
\hline Kultura & 8 & 15,69 \\
\hline & & \\
\hline
\end{tabular}


Психолого-педагогічні науки. 2020. № 2

\begin{tabular}{|l|c|c|}
\hline \hline Spokój wewnętrzny & 7 & 13,73 \\
\hline Wolność osobista & 7 & 13,73 \\
\hline Poznanie świata & 6 & 11,76 \\
\hline Piękno & 5 & 9,80 \\
\hline Dobra materialne & 5 & 9,80 \\
\hline Patriotyzm & 4 & 7,84 \\
\hline $\begin{array}{l}\text { Odnalezienie swojego miejsca w wiecie } \\
\text { śwe }\end{array}$ & 4 & 7,84 \\
\hline Realizacja zadania życiowego & 4 & 7,84 \\
\hline Rozwój duchowy & 4 & 7,84 \\
\hline Spryt życiowy & 3 & 5,88 \\
\hline Wygodne życie & 3 & 5,88 \\
\hline Pozycja społeczna & 1 & 1,96 \\
\hline Władza & 1 & 1,96 \\
*dane nie sumują się, ponieważ badani wskazywali kilka wartości \\
Źródło: badania własne
\end{tabular}

Po zapoznaniu się z wartościami szczególnie cenionymi przez osoby dorosłe, które się kształcą zbadano, jakie wartości cenią osoby dorosłe, które się nie kształcą. W tabeli 2 w analogiczny sposób została stworzona i przedstawiona hierarchia wartości preferowanych przez te osoby.

Tabela 2

Hierarchia wartości preferowanych przez osoby dorosłe, które się nie kształcą

\begin{tabular}{|l|c|c|}
\hline \multirow{2}{*}{ Wartośćc } & \multicolumn{2}{|c|}{$\mathbf{N}=\mathbf{4 7}$} \\
\cline { 2 - 3 } & $\mathbf{n}$ & $\%$ \\
\hline Zdrowie & 33 & 70,21 \\
\hline Miłość & 28 & 59,57 \\
\hline Szacunek & 26 & 55,32 \\
\hline Prawda & 22 & 46,80 \\
\hline Rodzina & 21 & 44,68 \\
\hline Godność osobowa & 20 & 42,55 \\
\hline Pomoc innym ludziom & 18 & 38,30 \\
\hline Radość życia & 17 & 36,17 \\
\hline Pokój & 17 & 36,17 \\
\hline Przyjaźń & 16 & 34,04 \\
\hline Dobro moralne & 15 & 31,91 \\
\hline Sprawiedliwość & 13 & 27,66 \\
\hline Życie towarzyskie & 13 & 27,66 \\
\hline Szczęście osobiste & 13 & 27,66 \\
\hline Zabezpieczenie bytu & 13 & 27,66 \\
\hline Praca zawodowa & 13 & 27,66 \\
\hline Samodzielność & 12 & 25,53 \\
\hline Wolność osobista & 12 & 25,53 \\
\hline Wiara w Boga & 11 & 23,40 \\
\hline Dobra materialne & 10 & 21,28 \\
\hline Zainteresowania & 10 & 21,28 \\
\hline Własny rozwój & 10 & 21,28 \\
\hline Umiejętność współżycia z ludźmi & 10 & 21,28 \\
\hline Piękno & 9 & 19,14 \\
\hline Kontakt z przyrodą & 8 & 17,02 \\
\hline Spryt życiowy & 7 & 14,89 \\
\hline Wiedza & 7 & 14,89 \\
\hline
\end{tabular}




\begin{tabular}{|l|c|c|}
\hline Kultura & 7 & 14,89 \\
\hline Spokój wewnętrzny & 7 & 14,89 \\
\hline Kształtowanie charakteru & 6 & 12,77 \\
\hline Mądrość & 6 & 12,77 \\
\hline Wygodne życie & 6 & 12,77 \\
\hline Poznanie świata & 5 & 10,64 \\
\hline Patriotyzm & 4 & 8,51 \\
\hline Władza & 4 & 8,51 \\
\hline Realizacja zadania życiowego & 4 & 8,51 \\
\hline Rozwój duchowy swojego miejsca w & 3 & 8,51 \\
\hline $\begin{array}{l}\text { Odnalezienie śriecie } \\
\text { świec| }\end{array}$ & 3 & 6,38 \\
\hline Wykształcenie & 2 & 6,38 \\
\hline Pozycja społeczna & 3,26 \\
\hline
\end{tabular}

*dane nie sumują się, ponieważ badani wskazywali kilka wartości

Źródło: badania własne

Najbardziej cenią wartością dla osób badanych, które się nie kształcą, podobnie jak w przypadku osób kształcących się jest zdrowie, co deklaruje 70,21 \% badanych. Wysoko umiejscawiają oni w hierarchii również takie wartości jak: miłość $(59,57 \%)$, szacunek $(55,32 \%)$, prawda $(46,80 \%)$ oraz rodzina $(44,68 \%)$. Najmniej cenionymi wartościami dla osób dorosłych, które się nie kształcą, są takie wartości jak: pozycja społeczna $(4,26 \%)$, wykształcenie $(6,38 \%)$, odnalezienie swojego miejsca w świecie $(6,38 \%)$ i rozwój duchowy $(8,51 \%)$.

Przeprowadzone analizy pokazały, że osoby z tej grupy badawczej w przeciwieństwie do badanych, którzy się uczą, nie rangują zbyt wysoko wartości związanych w nauką; są to takie wartości jak wiedza, wskazywana przez 14,89\%, wykształcenie $(6,38 \%)$, mądrość $(12,77 \%)$ oraz wartości z nią związanych, czyli: własny rozwój czy zainteresowania, wskazywane przez $21,88 \%$ badanych $z$ tej grupy.

$\mathrm{Na}$ podstawie przedstawionych analiz, pomimo, że na szczycie hierarchii wartości osób z dwóch grup badawczych znalazły się podobne wartości, są zauważalne różnice w preferencji niektórych z nich pomiędzy osobami, które się kształcą oraz osobami, które się nie kształcą. Wynika z tego, że podjęty proces kształcenia ma wpływ na kształt hierarchii wartości człowieka, wpływa różnicująco.

Kształt hierarchii wartości człowieka uzależniony jest od wielu czynników. Należą do nich między innymi: wiek człowieka, jego miejsce zamieszkania i związane z tym środowisko życia czy płeć.

Po zapoznaniu się z hierarchią wartości preferowanych przez osoby badane z dwóch grup, sprawdzono również, jaki jest wpływ płci badanych na kształt ich hierarchii wartości; czy płeć wpływa różnicująco na kształt preferowanych przez nich wartości. W pierwszej kolejności zbadano czy istnieją różnice $\mathrm{w}$ preferencji wartości pomiędzy mężczyznami oraz kobietami, którzy podejmują naukę. W tabeli 3 przedstawiono wartości, które są szczególnie cenione przez mężczyzn oraz kobiety, którzy się kształcą.

Jak wynika $z$ danych zawartych $w$ tabeli 3 na szczycie hierarchii wartości preferowanych przez kobiety oraz mężczyzn, którzy się kształcą znalazły się takie wartości jak: zdrowie, miłość, rodzina. Mężczyźni wysoko cenią również wiedzę (64,75\%), a najmniej cenioną wartością wśród mężczyzn są dobra materialne, pozycja społeczna, władza, spryt życiowy, które nie zostały wskazane przez żadnego z nich. Kobiety natomiast najmniej cenią taką wartość jak władza, która została wskazana tylko przez jedną z uczestniczących $w$ badaniach kobiet. Pomimo niewielkich różnic ogólny kształt dwóch hierarchii jest zbliżony. Kilka wartości znalazło się na tej samej pozycji w hierarchii zarówno wśród kobiet jak i mężczyzn. Są to takie wartości jak: umiejętność współżycia z ludźmi, kultura, zabezpieczenie bytu, zainteresowania oraz radość życia. Pewne różnice występują w rangowaniu 5 spośród 40 wartości przez badanych mężczyzn oraz kobiety. Różnice te dotyczą między innymi, takich wartości jak prawda, szczęście osobiste czy kształtowanie charakteru. Wszelkie pozostałe znaczące różnice zostały zaznaczone w tabeli 3. 
Tabela 3

Hierarchia wartości preferowanych przez kobiety oraz mężczyzn kształcących się

\begin{tabular}{|c|c|c|c|c|c|}
\hline \multicolumn{3}{|c|}{$\begin{array}{c}\text { Hierarchia wartości mężczyzn, którzy } \\
\text { się kształcą }\end{array}$} & \multicolumn{3}{|c|}{$\begin{array}{c}\text { Hierarchia wartości kobiet, które się } \\
\text { kształcą }\end{array}$} \\
\hline \multirow[t]{2}{*}{ Wartość } & \multicolumn{2}{|c|}{$\mathrm{N}=17$} & \multirow[t]{2}{*}{ Wartość } & \multicolumn{2}{|c|}{$\mathrm{N}=34$} \\
\hline & $\mathbf{n}$ & $\%$ & & $\mathbf{n}$ & $\%$ \\
\hline Miłość & 11 & 64,75 & Zdrowie & 25 & 73,53 \\
\hline Wiedza & 11 & 64,75 & Rodzina & 22 & 64,71 \\
\hline Rodzina & 11 & 64,75 & Miłość & 21 & 61,76 \\
\hline Zdrowie & 10 & 58,82 & Szacunek & 17 & 50,00 \\
\hline Mądrość & 9 & 52,94 & Własny rozwój & 15 & 44,12 \\
\hline Szacunek & 9 & 52,94 & Wiedza & 14 & 41,17 \\
\hline Własny rozwój & 7 & 41,18 & Pomoc innym ludziom & 13 & 38,24 \\
\hline Szczęście osobiste & 7 & 41,18 & Godność osobowa & 13 & 38,24 \\
\hline Zainteresowania & 7 & 41,18 & Zainteresowania & 12 & 35,29 \\
\hline Wykształcenie & 7 & 41,18 & Prawda & 12 & 35,29 \\
\hline Praca zawodowa & 6 & 35,29 & Mądrość & 12 & 35,29 \\
\hline Pomoc innym ludziom & 6 & 35,29 & Przyjaźń & 11 & 32,35 \\
\hline $\begin{array}{l}\text { Umiejętność współżycia } \\
\text { z ludźmi }\end{array}$ & 6 & 35,29 & $\begin{array}{l}\text { Umiejętność } \\
\text { współżycia z ludźmi }\end{array}$ & 10 & 29,41 \\
\hline $\begin{array}{l}\text { Kształtowanie } \\
\text { charakteru }\end{array}$ & 6 & 35,29 & Wykształcenie & 10 & 29,41 \\
\hline Dobro moralne & 6 & 35,29 & Praca zawodowa & 10 & 29,41 \\
\hline Godność osobowa & 4 & 23,53 & Pokój & 10 & 29,41 \\
\hline Prawda & 4 & 23,53 & Dobro moralne & 10 & 29,41 \\
\hline Przyjaźń & 4 & 23,53 & Wiara w Boga & 9 & 26,47 \\
\hline Sprawiedliwość & 4 & 23,53 & Szczęście osobiste & 9 & 26,47 \\
\hline Kontakt z przyroda & 4 & 23,53 & Sprawiedliwość & 9 & 26,47 \\
\hline Zabezpieczenie bytu & 4 & 23,53 & Zabezpieczenie bytu & 8 & 23,53 \\
\hline Wiara w Boga & 4 & 23,53 & Samodzielność & 8 & 23,53 \\
\hline Radość życia & 3 & 17,65 & Radość życia & 8 & 23,53 \\
\hline Spokój wewnętrzny & 3 & 17,65 & Życie towarzyskie & 7 & 20,59 \\
\hline Kultura & 2 & 11,76 & Kultura & 6 & 17,65 \\
\hline Patriotyzm & 2 & 11,76 & $\begin{array}{l}\text { Kształtowanie } \\
\text { charakteru }\end{array}$ & 6 & 17,65 \\
\hline Pokój & 2 & 11,76 & Kontakt z przyrodą & 6 & 17,65 \\
\hline Samodzielność & 2 & 11,76 & Wolność osobista & 6 & 17,65 \\
\hline Poznanie świata & 2 & 11,76 & Dobra materialne & 5 & 14,71 \\
\hline $\begin{array}{l}\text { Odnalezienie swojego } \\
\text { miejsca w świecie }\end{array}$ & 2 & 11,76 & Spokój wewnętrzny & 4 & 11,76 \\
\hline Życie towarzyskie & 2 & 11,76 & Poznanie świata & 4 & 11,76 \\
\hline Wolność osobista & 1 & 5,88 & Piękno & 4 & 11,76 \\
\hline Wygodne życie & 1 & 5,88 & Rozwój duchowy & 3 & 8,82 \\
\hline Rozwój duchowy & 1 & 5,88 & Spryt życiowy & 3 & 8,82 \\
\hline $\begin{array}{l}\text { Realizacja zadania } \\
\text { życiowego }\end{array}$ & 1 & 5,88 & $\begin{array}{l}\text { Realizacja zadania } \\
\text { życiowego }\end{array}$ & 3 & 8,82 \\
\hline Piękno & 1 & 5,88 & Wygodne życie & 2 & 5,88 \\
\hline Spryt życiowy & 0 & 0,00 & $\begin{array}{l}\text { Odnalezienie swojego } \\
\text { miejsca w świcie }\end{array}$ & 2 & 5,88 \\
\hline Władza & 0 & 0,00 & Patriotyzm & 2 & 5,88 \\
\hline Pozycja społeczna & 0 & 0,00 & Pozycja społeczna & 1 & 2,94 \\
\hline Dobra materialne & 0 & 0,00 & Władza & 1 & 2,94 \\
\hline
\end{tabular}

*dane nie sumuja się, ponieważ badani wskazywali kilka wartości

Źródło: badania własne 
Następnie zbadano, czy istnieją różnice w preferencji wartości wśród kobiet i mężczyzn biorących udział w badaniach, którzy się nie kształcą. W tabeli 4 przedstawiono otrzymane wyniki.

Z przedstawionych w poniższej tabeli danych wynika, że zarówno w przypadku kobiet, jak i mężczyzn, którzy się nie kształcą na szczycie hierarchii wartości preferowanych znalazły się dokładnie te same wartości, w takich samych rangach. Są to takie wartości jak: zdrowie, rodzina, miłość, szacunek oraz prawda. Żaden z badanych mężczyzn nie ceni wykształcenia oraz odnalezienia swojego miejsca w świecie, natomiast do najmniej cenionych wartości wśród kobiet należą: realizacja zadania życiowego oraz pozycja społeczna, wskazywane przez jedną z badanych z tej grupy kobiet. Tę samą rangę, w przypadku kobiet, jaki i mężczyzn otrzymały takie wartości jak: samodzielność, spokój wewnętrzny, kultura, spryt życiowy oraz własny rozwój i dobra materialne. Dość duże różnice zaobserwowano w hierarchizacji takich wartości jak: wykształcenie, życie towarzyskie czy mądrość, które były bardziej cenione przez mężczyzn. Wszystkie pozostałe i znaczące różnice w pozycji wartości w hierarchii wartości badanych kobiet i mężczyzn z tej grupy zostały zaznaczone w tabeli 4.

Tabela 4

\section{Hierarchia wartości preferowanych przez kobiety oraz mężczyzn, którzy się nie kształcą}

\begin{tabular}{|c|c|c|c|c|c|}
\hline \multicolumn{3}{|c|}{$\begin{array}{c}\text { Hierarchia wartości mężczyzn, którzy } \\
\text { się nie kształcą }\end{array}$} & \multicolumn{3}{|c|}{$\begin{array}{c}\text { Hierarchia wartości kobiet, które się } \\
\text { nie kształcą }\end{array}$} \\
\hline \multirow[t]{2}{*}{ Wartość } & \multicolumn{2}{|c|}{$\mathrm{N}=19$} & \multirow[t]{2}{*}{ Wartość } & \multicolumn{2}{|c|}{$\mathrm{N}=\mathbf{2 8}$} \\
\hline & $\mathbf{n}$ & $\%$ & & $\mathbf{n}$ & $\%$ \\
\hline Zdrowie & 13 & 68,42 & Zdrowie & 20 & 71,43 \\
\hline Rodzina & 11 & 57,89 & Rodzina & 20 & 71,43 \\
\hline Miłość & 11 & 57,89 & Miłość & 17 & 60,71 \\
\hline Szacunek & 10 & 52,63 & Szacunek & 16 & 57,14 \\
\hline Prawda & 10 & 52,63 & Prawda & 12 & 42,86 \\
\hline Pokój & 10 & 52,63 & Godność osobowa & 11 & 39,29 \\
\hline Godność osobowa & 9 & 47,37 & Pomoc innym ludziom & 11 & 39,29 \\
\hline Radość życia & 7 & 36,84 & Dobro moralne & 10 & 35,71 \\
\hline Pomoc innym ludziom & 7 & 36,84 & Przyjaźń & 10 & 35,71 \\
\hline Praca zawodowa & 6 & 31,58 & Życie towarzyskie & 9 & 32,14 \\
\hline Sprawiedliwość & 6 & 31,58 & Zabezpieczenie bytu & 8 & 28,57 \\
\hline Przyjaźń & 6 & 31,58 & Szczęście osobiste & 8 & 28,57 \\
\hline Dobro moralne & 5 & 26,32 & Wiara w Boga & 7 & 25,00 \\
\hline Szczęście osobiste & 5 & 26,32 & Praca zawodowa & 7 & 25,00 \\
\hline Wolność osobista & 5 & 26,32 & Wolność osobista & 7 & 25,00 \\
\hline Samodzielność & 5 & 26,32 & Samodzielność & 7 & 25,00 \\
\hline Zabezpieczenie bytu & 5 & 26,32 & Sprawiedliwość & 7 & 25,00 \\
\hline Zainteresowania & 5 & 26,32 & Radość życia & 7 & 25,00 \\
\hline Życie towarzyskie & 4 & 21,05 & Pokój & 7 & 25,00 \\
\hline Wiara w Boga & 4 & 21,05 & Piękno & 6 & 21,43 \\
\hline Dobra materialne & 4 & 21,05 & Dobra materialne & 6 & 21,43 \\
\hline Własny rozwój & 4 & 21,05 & Własny rozwój & 6 & 21,43 \\
\hline $\begin{array}{l}\text { Umiejętność współżycia } \\
\text { z ludźmi }\end{array}$ & 4 & 21,05 & $\begin{array}{l}\text { Umiejętność } \\
\text { współżycia z ludźmi }\end{array}$ & 6 & 21,43 \\
\hline Wygodne życie & 3 & 15,79 & Zainteresowania & 5 & 17.86 \\
\hline Mądrość & 3 & 15,79 & Kontakt z przyrodą & 5 & 17.86 \\
\hline Piękno & 3 & 15,79 & Wiedza & 5 & 17.86 \\
\hline Kultura & 3 & 15,79 & Kultura & 4 & 14,29 \\
\hline Spryt życiowy & 3 & 15,79 & Spryt życiowy & 4 & 14,29 \\
\hline Spokój wewnętrzny & 3 & 15,79 & Spokój wewnętrzny & 4 & 14,29 \\
\hline
\end{tabular}




\begin{tabular}{|c|c|c|c|c|c|}
\hline Kontakt z przyrodą & 3 & 15,79 & $\begin{array}{l}\text { Kształtowanie } \\
\text { charakteru }\end{array}$ & 4 & 14,29 \\
\hline $\begin{array}{l}\text { Realizacja zadania } \\
\text { życiowego }\end{array}$ & 3 & 15,79 & Wykształcenie & 3 & 10,71 \\
\hline Poznanie świata & 2 & 10,53 & Wygodne życie & 3 & 10,71 \\
\hline $\begin{array}{l}\text { Kształtowanie } \\
\text { charakteru }\end{array}$ & 2 & 10,53 & Poznanie świata & 3 & 10,71 \\
\hline Wiedza & 2 & 10,53 & Patriotyzm & 3 & 10,71 \\
\hline Pozycja społeczna & 1 & 5,26 & Władza & 3 & 10,71 \\
\hline Władza & 1 & 5,26 & Mądrość & 3 & 10,71 \\
\hline Rozwój duchowy & 1 & 5,26 & $\begin{array}{l}\text { Odnalezienie swojego } \\
\text { miejsca w świcie }\end{array}$ & 3 & 10,71 \\
\hline Patriotyzm & 1 & 5,26 & Rozwój duchowy & 3 & 10,71 \\
\hline $\begin{array}{l}\text { Odnalezienie swojego } \\
\text { miejsca w świecie }\end{array}$ & 0 & 0,00 & Pozycja społeczna & 1 & 3,57 \\
\hline Wykształcenie & 0 & 0,00 & $\begin{array}{l}\text { Realizacja zadania } \\
\text { życiowego }\end{array}$ & 1 & 3,57 \\
\hline
\end{tabular}

*dane nie sumują się, ponieważ badani wskazywali kilka wartości

Źródło: badania własne

Po zapoznaniu się z różnicami w preferencji wartości przez kobiety oraz mężczyzn $z$ dwóch grup badawczych (kształcących się i nie kształcących się) zbadano, czy istnieją różnice $w$ obrębie jednej płci $w$ preferencji wartości - pomiędzy kobietami, które się kształcą i tymi, które się nie kształcą i analogicznie pomiędzy mężczyznami z dwóch grup. W tabeli 5 oraz 6 przedstawiono otrzymane wyniki.

Po dokonaniu analizy porównawczej hierarchii wartości mężczyzn z obu grup wynika, że najbardziej cenioną wartością dla mężczyzn, którzy się kształcą jest miłość (64,75\%), zaś najmniej cenione są dobra materialne, pozycja społeczna, władza oraz spryt życiowy. Wartości te nie zostały wskazane przez żadnego z badanych mężczyzn. Natomiast mężczyźni, którzy się nie kształcą najbardziej cenią wartość zdrowia $(68,42 \%)$, zaś najmniej wykształcenie oraz odnalezienie swojego miejsca w świecie, których nie wskazał żaden mężczyzna z tej grupy. W analizie porównawczej bardziej widoczna jest różnica w preferencji niektórych wartości, które często uzyskiwały dość skrajne rangi, np. taka wartość jak wiedza czy wykształcenie, w dwóch grupach badawczych. Mężczyźni, którzy się kształcą wyżej rangowali wartości związane z nauką (wykształcenie, mądrość, wiedza) oraz wartości związane $z$ własnym rozwojem i rozwijaniem swoich pasji i zainteresowań. $Z$ kolei mężczyźni, którzy się nie kształcą wyżej umiejscawiali w swojej hierarchii takie wartości jak: spryt życiowy, dobra materialne czy wygodne życie. Wszelkie istotne różnice dotyczące zmian w preferencji wartości zostały zaznaczone w tabeli 5. Na tej samej pozycji w hierarchii mężczyzn z dwóch grup znalazły się takie wartości jak: władza, kultura, wiara w Boga, a także dobro moralne i praca zawodowa.

Tabela 5

Hierarchia wartości preferowanych przez mężczyzn, którzy się kształcą i mężczyzn, którzy się nie kształcą

\begin{tabular}{|c|c|c|c|c|c|}
\hline \multicolumn{3}{|c|}{$\begin{array}{l}\text { Hierarchia wartości mężczyzn, którzy } \\
\text { się kształcą }\end{array}$} & \multicolumn{3}{|c|}{$\begin{array}{l}\text { Hierarchia wartości mężczyzn, którzy } \\
\text { się nie kształcą }\end{array}$} \\
\hline \multirow[t]{2}{*}{ Wartość } & \multicolumn{2}{|c|}{$\mathrm{N}=17$} & \multirow[t]{2}{*}{ Wartość } & \multicolumn{2}{|c|}{$N=19$} \\
\hline & $n$ & $\%$ & & $n$ & $\%$ \\
\hline Miłość & 11 & 64,75 & Zdrowie & 13 & 68,42 \\
\hline Wiedza & 11 & 64,75 & Rodzina & 11 & 57,89 \\
\hline Rodzina & 11 & 64,75 & Miłość & 11 & 57,89 \\
\hline Zdrowie & 10 & 58,82 & Szacunek & 10 & 52,63 \\
\hline Mądrość & 9 & 52,94 & Prawda & 10 & 52,63 \\
\hline Szacunek & 9 & 52,94 & Pokój & 10 & 52,63 \\
\hline
\end{tabular}




\begin{tabular}{|c|c|c|c|c|c|}
\hline Własny rozwój & 7 & 41,18 & Godność osobowa & 9 & 47,37 \\
\hline Zainteresowania & 7 & 41,18 & Radość życia & 7 & 36,84 \\
\hline Szczęście osobiste & 7 & 41,18 & Pomoc innym ludziom & 7 & 36,84 \\
\hline Wykształcenie & 7 & 41,18 & Sprawiedliwość & 6 & 31,58 \\
\hline Praca zawodowa & 6 & 35,29 & Praca zawodowa & 6 & 31,58 \\
\hline $\begin{array}{l}\text { Umiejętność współżycia } \\
\text { z ludźmi }\end{array}$ & 6 & 35,29 & Przyjaźń & 6 & 31,58 \\
\hline Dobro moralne & 6 & 35,29 & Dobro moralne & 5 & 26,32 \\
\hline Pomoc innym ludziom & 6 & 35,29 & Szczeście osobiste & 5 & 26,32 \\
\hline $\begin{array}{l}\text { Kształtowanie } \\
\text { charakteru }\end{array}$ & 6 & 35,29 & Wolność osobista & 5 & 26,32 \\
\hline Godność osobowa & 4 & 23,53 & Samodzielność & 5 & 26,32 \\
\hline Prawda & 4 & 23,53 & Zabezpieczenie bytu & 5 & 26,32 \\
\hline Przyjaźń & 4 & 23,53 & Zainteresowania & 5 & 26,32 \\
\hline Sprawiedliwość & 4 & 23,53 & Życie towarzyskie & 4 & 21,05 \\
\hline Kontakt z przyrodą & 4 & 23,53 & $\begin{array}{l}\text { Umiejętność współżycia } \\
\text { z ludźmi }\end{array}$ & 4 & 21,05 \\
\hline Zabezpieczenie bytu & 4 & 23,53 & Dobra materialne & 4 & 21,05 \\
\hline Wiara w Boga & 4 & 23,53 & Wiara w Boga & 4 & 21,05 \\
\hline Radość życia & 3 & 17,65 & Własny rozwój & 4 & 21,05 \\
\hline Spokój wewnętrzny & 3 & 17,65 & Wygodne życie & 3 & 15,79 \\
\hline Patriotyzm & 2 & 11,76 & Mądrość & 3 & 15,79 \\
\hline Pokój & 2 & 11,76 & Piękno & 3 & 15,79 \\
\hline Kultura & 2 & 11,76 & Kultura & 3 & 15,79 \\
\hline Samodzielność & 2 & 11,76 & Spryt życiowy & 3 & 15,79 \\
\hline Poznanie świata & 2 & 11,76 & Spokój wewnętrzny & 3 & 15,79 \\
\hline $\begin{array}{l}\text { Odnalezienie swojego } \\
\text { miejsca w świecie }\end{array}$ & 2 & 11,76 & Kontakt z przyrodą & 3 & 15,79 \\
\hline Życie towarzyskie & 2 & 11,76 & $\begin{array}{l}\text { Realizacja zadania } \\
\text { życiowego }\end{array}$ & 3 & 15,79 \\
\hline Wolność osobista & 1 & 5,88 & Poznanie świata & 2 & 10,53 \\
\hline Wygodne życie & 1 & 5,88 & $\begin{array}{l}\text { Kształtowanie } \\
\text { charakteru }\end{array}$ & 2 & 10,53 \\
\hline Rozwój duchowy & 1 & 5,88 & Wiedza & 2 & 10,53 \\
\hline $\begin{array}{l}\text { Realizacja zadania } \\
\text { życiowego }\end{array}$ & 1 & 5,88 & Pozycja społeczna & 1 & 5,26 \\
\hline Piękno & 1 & 5,88 & Rozwój duchowy & 1 & 5,26 \\
\hline Władza & 0 & 0,00 & Władza & 1 & 5,26 \\
\hline Spryt życiowy & 0 & 0,00 & Patriotyzm & 1 & 5,26 \\
\hline Pozycja społeczna & 0 & 0,00 & $\begin{array}{l}\text { Odnalezienie swojego } \\
\text { miejsca w świecie }\end{array}$ & 0 & 0,00 \\
\hline Dobra materialne & 0 & 0,00 & Wykształcenie & 0 & 0,00 \\
\hline
\end{tabular}

*dane nie sumują się, ponieważ badani wskazywali kilka wartości

Źródło: badania własne

Analogicznej analizy porównawczej dokonano w przypadku kobiet $z$ dwóch grup badawczych. Otrzymane wyniki przedstawiono w tabeli 6. 
Hierarchia wartości preferowanych przez kobiety, które się kształcą oraz kobiety, które się nie kształcą

\begin{tabular}{|c|c|c|c|c|c|}
\hline \multicolumn{3}{|c|}{$\begin{array}{c}\text { Hierarchia wartości kobiet, które się } \\
\text { kształcą }\end{array}$} & \multicolumn{3}{|c|}{$\begin{array}{c}\text { Hierarchia wartości kobiet, które się } \\
\text { nie kształcą }\end{array}$} \\
\hline \multirow[t]{2}{*}{ Wartość } & \multicolumn{2}{|c|}{$\mathrm{N}=34$} & \multirow[t]{2}{*}{ Wartość } & \multicolumn{2}{|c|}{$\mathrm{N}=\mathbf{2 8}$} \\
\hline & $\mathbf{n}$ & $\%$ & & $\mathbf{n}$ & $\%$ \\
\hline Zdrowie & 25 & 73,53 & Zdrowie & 20 & 71,43 \\
\hline Rodzina & 22 & 64,71 & Rodzina & 20 & 71,43 \\
\hline Miłość & 21 & 61,76 & Miłość & 17 & 60,71 \\
\hline Szacunek & 17 & 50,00 & Szacunek & 16 & 57,14 \\
\hline Własny rozwój & 15 & 44,12 & Prawda & 12 & 42,86 \\
\hline Wiedza & 14 & 41,17 & Godność osobowa & 11 & 39,29 \\
\hline Pomoc innym ludziom & 13 & 38,24 & Pomoc innym ludziom & 11 & 39,29 \\
\hline Godność osobowa & 13 & 38,24 & Dobro moralne & 10 & 35,71 \\
\hline Zainteresowania & 12 & 35,29 & Przyjaźń & 10 & 35,71 \\
\hline Prawda & 12 & 35,29 & Życie towarzyskie & 9 & 32,14 \\
\hline Mądrość & 12 & 35,29 & Zabezpieczenie bytu & 8 & 28,57 \\
\hline Przyjaźń & 11 & 32,35 & Szczęście osobiste & 8 & 28,57 \\
\hline $\begin{array}{l}\text { Umiejętność } \\
\text { współżycia z ludźmi }\end{array}$ & 10 & 29,41 & Samodzielność & 7 & 25,00 \\
\hline Wykształcenie & 10 & 29,41 & Wolność osobista & 7 & 25,00 \\
\hline Praca zawodowa & 10 & 29,41 & Praca zawodowa & 7 & 25,00 \\
\hline Pokój & 10 & 29,41 & Wiara w Boga & 7 & 25,00 \\
\hline Dobro moralne & 10 & 29,41 & Sprawiedliwość & 7 & 25,00 \\
\hline Wiara w Boga & 9 & 26,47 & Radość życia & 7 & 25,00 \\
\hline Szczęście osobiste & 9 & 26,47 & Pokój & 7 & 25,00 \\
\hline Sprawiedliwość & 9 & 26,47 & Piękno & 6 & 21,43 \\
\hline Radość życia & 8 & 23,53 & Własny rozwój & 6 & 21,43 \\
\hline Samodzielność & 8 & 23,53 & Dobra materialne & 6 & 21,43 \\
\hline Zabezpieczenie bytu & 8 & 23,53 & $\begin{array}{l}\text { Umiejętność } \\
\text { współżycia z ludźmi }\end{array}$ & 6 & 21,43 \\
\hline Życie towarzyskie & 7 & 20,59 & Zainteresowania & 5 & 17.86 \\
\hline Kontakt z przyrodą & 6 & 17,65 & Kontakt z przyrodą & 5 & 17.86 \\
\hline $\begin{array}{l}\text { Kształtowanie } \\
\text { charakteru }\end{array}$ & 6 & 17,65 & Wiedza & 5 & 17.86 \\
\hline Kultura & 6 & 17,65 & Spryt życiowy & 4 & 14,29 \\
\hline Wolność osobista & 6 & 17,65 & Spokój wewnętrzny & 4 & 14,29 \\
\hline Dobra materialne & 5 & 14,71 & Kultura & 4 & 14,29 \\
\hline Spokój wewnętrzny & 4 & 11,76 & $\begin{array}{l}\text { Kształtowanie } \\
\text { charakteru }\end{array}$ & 4 & 14,29 \\
\hline Poznanie świata & 4 & 11,76 & Poznanie świata & 3 & 10,71 \\
\hline Piękno & 4 & 11,76 & Wygodne życie & 3 & 10,71 \\
\hline Rozwój duchowy & 3 & 8,82 & Wykształcenie & 3 & 10,71 \\
\hline Spryt życiowy & 3 & 8,82 & Patriotyzm & 3 & 10,71 \\
\hline $\begin{array}{l}\text { Realizacja zadania } \\
\text { życiowego }\end{array}$ & 3 & 8,82 & Władza & 3 & 10,71 \\
\hline Wygodne życie & 2 & 5,88 & Mądrość & 3 & 10,71 \\
\hline $\begin{array}{l}\text { Odnalezienie swojego } \\
\text { miejsca w świcie }\end{array}$ & 2 & 5,88 & $\begin{array}{l}\text { Odnalezienie swojego } \\
\text { miejsca w świcie }\end{array}$ & 3 & 10,71 \\
\hline Patriotyzm & 2 & 5,88 & Rozwój duchowy & 3 & 10,71 \\
\hline Pozycja społeczna & 1 & 2,94 & Pozycja społeczna & 1 & 3,57 \\
\hline Władza & 1 & 2,94 & $\begin{array}{l}\text { Realizacja zadania } \\
\text { życiowego }\end{array}$ & 1 & 3,57 \\
\hline
\end{tabular}

*dane nie sumują się, ponieważ badani wskazywali kilka wartości

Źródło: badania własne 
Przeprowadzona analiza pokazuje, że zarówno kobiety, które się kształcą i te, które nie podejmują nauki, najbardziej cenią takie wartości jak: zdrowie, rodzina, miłość oraz szacunek. Najmniej cenionymi wartościami dla kobiet, które się kształcą są władza oraz pozycja społeczna, wybrane przez jedną z badanych, a także patriotyzm wskazany przez $5,88 \%$ badanych, zaś dla kobiet nie kształcących się do najmniej cenionych wartości należą: realizacja zadania życiowego i pozycja społeczna wybierane przez jedną z badanych kobiet oraz rozwój duchowy wskazany przez trzy badane. Na tej samej pozycji w dwóch hierarchiach znalazły się takie wartości jak: kontakt z przyrodą, odnalezienie swojego miejsca w świecie, praca zawodowa, zdrowie, rodzina, miłość, szacunek oraz poznawanie świata. W przypadku kobiet $z$ dwóch grup widoczne są różnice, czasami dość znaczące w preferencji niektórych wartości. Kobiety kształcące się bardziej cenią wartość mądrości, wykształcenia czy zainteresowań oraz własnego rozwoju. Kobiety, które się nie kształcą bardziej cenią samodzielność, piękno czy zabezpieczenie bytu. Wszystkie różnice $\mathrm{w}$ preferencji określonych wartości przez kobiety $\mathrm{z}$ dwóch grup badawczych zostały zaznaczone w tabeli 6.

Po dokonanych analizach wpływu płci badanych na kształt ich hierarchii wartości zauważono, że płeć badanych wpływa różnicująco na ich system wartości. Różnice te dotyczą niektórych wartości. Duże różnice w preferencji wartości dostrzegane są jednak w obrębie tej samej płci, ale reprezentujące różne grupy badawcze (pomiędzy kobietami uczącymi się i nie uczącymi się oraz analogicznie wśród mężczyzn). Można wnioskować, że różnice te jednak nie wynikają tylko i wyłącznie z różnicy płci, lecz istotnego wpływu uczestnictwa tych badanych $\mathrm{w}$ procesie kształcenia, co przekłada się na różnice $\mathrm{w}$ wartościowaniu i postrzeganiu w odmienny sposób pewnych wartości.

Podsumowanie. Jak wspomniano na wstępie artykułu, z procesem edukacji nierozerwalnie łączą się wartości. Podjęte badania miały ukazać, jaka jest ich rola w procesie kształcenia dorosłych oraz jakie wartości preferują osoby dorosłe, które się kształcą i czy istnieje różnica $w$ ich preferencjach pomiędzy osobami, które się kształcą oraz tymi, którzy nie podejmują procesu kształcenia. Uzyskane wyniki pokazały, że proces kształcenia wpływa na kształt hierarchii wartości człowieka niezależnie od wieku. Pomiędzy osobami uczącymi się oraz tymi, które się nie kształcą, uczestniczącymi w prowadzonych badaniach istnieją różnice $\mathrm{w}$ rangowaniu wartości.

\section{Bibliografia}

1. Chałas K. Społeczno-kulturowe uwarunkowania wyboru i afirmacji wartości środowiskowych przez młodzież z gimnazjów wiejskich, [w:] Wartości w pedagogice. Rodzina i szkoła środowiskami urzeczywistniania wartości, red. W. Furmanek, A. Długosz, Wydawnictwo Uniwersytetu Rzeszowskiego, Rzeszów 2015.

2. Czakon-Tralski D, Borecka W. To co w życiu ważne czyli hierarchia wartości polskich $i$ białoruskich studentów, Wydawnictwo Politechniki Śląskiej w Gliwicach, Gliwice 2018. S. 131142: URL: https://www.polsl.pl/Wydzialy/ROZ/ZN/Documents/zeszyt\%20123/CzakonTralski,\%20Borecka.pdf

3. Denek K. Wartości w edukacji szkolnej, [w:] Wartości w pedagogice, red. W. Furmanek, Wydawnictwo Uniwersytetu Rzeszowskiego, Rzeszów-Warszawa 2005.

4. Denek K. Wartości w kontekście edukacji i nauk o niej, [w:] Wartości w pedagogice. Urzeczywistnianie wartości, red. W. Furmanek, A. Długosz, Wydawnictwo Uniwersytetu Rzeszowskiego, Rzeszów 2015. s. 11-41.

5. Długosz A. Rozwijanie umiejętności wykorzystania czasu zadaniem rodziców w procesach wychowania do wartości, Wydawnictwo Uniwersytetu Rzeszowskiego, Rzeszów 2015. $341 \mathrm{~s}$.

6. Ignatczyk W. System wartości rodzinnych młodzieży polskiej końca XX wieku, Wydawnictwo Akademii Ekonomicznej w Poznaniu, Centrum Badań nad Rodziną, Poznań 2002. S. 17-22.

7. Łobocki M. W trosce o wychowanie w szkole, Oficyna Wydawnicza "Impuls", Kraków 2007. $310 \mathrm{~s}$.

8. Nowak S. System wartości społeczeństwa polskiego, Uniwersytet Warszawski. Studia so cjologiczne. 2011. 1 (200). S. 261-278.

9. Ostrowska U. Wartość, [w:] Encyklopedia Aksjologii Pedagogicznej, red. K. Chałas, A. Maj, POLWEN, Polskie Wydawnictwo Encyklopedyczne, Radom 2016. 1572 s. 
10. Piątek T. Sztuka wydobywania człowieczeństwa - podstawowa wartość wychowania, Wydawnictwo Uniwersytetu Rzeszowskiego, Rzeszów 2015. S. 158-167.

11. Znaniecki F. Ludzie teraźniejsi a cywilizacja przyszłości, Wydawnictwo PWN, Warszawa 1974. $381 \mathrm{~s}$.

\section{References}

1. Chałas, K. (2015). Społeczno-kulturowe uwarunkowania wyboru i afirmacji wartości środowiskowych przez młodzież z gimnazjów wiejskich, [w:] Wartości w pedagogice [Sociocultural determinants of the choice and affirmation of environmental values by youth from rural junior high schools, [in:] Values in pedagogy]. Rodzina i szkoła środowiskami urzeczywistniania wartości - Family and school as environments of realizing values. W. Furmanek, A. Długosz (Ed.). Wydawnictwo Uniwersytetu Rzeszowskiego, Rzeszów [in Polish].

2. Czakon-Tralski, D \& Borecka, W. (2018). To co w życiu ważne czyli hierarchia wartości polskich i białoruskich studentów [What is important in life, i.e. the hierarchy of values of Polish and Belarusian students]. Wydawnictwo Politechniki Śląskiej w Gliwicach, Gliwice [in Polish].

3. Denek, K. (2005). Wartości w edukacji szkolnej, [w:] Wartości w pedagogice [Values in school education, [in:] Values in pedagogy]. Furmanek W. (Ed.). Wydawnictwo Uniwersytetu Rzeszowskiego, Rzeszów-Warszawa [in Polish].

4. Denek, K. (2015). Wartości w kontekście edukacji i nauk o niej, [w:] Wartości w pedagogice. Urzeczywistnianie wartości [Values in the context of education and science, [in:] Values in pedagogy. Realizing your values]. W. Furmanek, A. Długosz (Ed.). Wydawnictwo Uniwersytetu Rzeszowskiego, Rzeszów [in Polish].

5. Długosz, A. (2015). Rozwijanie umiejętności wykorzystania czasu zadaniem rodziców w procesach wychowania do wartości [Developing the ability to use time as the task of parents in the processes of education to values]. Wydawnictwo Uniwersytetu Rzeszowskiego, Rzeszów [in Polish].

6. Ignatczyk, W. (2002). System wartości rodzinnych młodzieży polskiej końca XX wieku [The system of family values of Polish youth at the end of the 20th century]. Wydawnictwo Akademii Ekonomicznej w Poznaniu, Centrum Badań nad Rodziną, Poznań [in Polish].

7. Łobocki, M. (2007). W trosce o wychowanie $w$ szkole [For the sake of education at school]. Oficyna, Wydawnicza "Impuls", Kraków [in Polish].

8. Nowak, S. (2011). System wartości społeczeństwa polskiego [The value system of Polish society]. Uniwersytet Warszawski, "Studia Socjologiczne 2011" [in Polish].

9. Ostrowska, U. (2016). Wartość, [w:] Encyklopedia Aksjologii Pedagogicznej [Value, [in:] Encyclopedia of Pedagogical Axiology]. K. Chałas, A. Maj (Ed.). POLWEN, Polskie Wydawnictwo Encyklopedyczne, Radom [in Polish].

10. Piątek, T. (2015). Sztuka wydobywania człowieczeństwa - podstawowa wartość wychowania [The art of bringing out humanity - the basic value of education]. Wydawnictwo Uniwersytetu Rzeszowskiego, Rzeszów [in Polish].

11.Znaniecki, F. (1974). Ludzie teraźniejsi a cywilizacja przyszłości [Present people and the civilization of the future]. Wydawnictwo PWN, Warszawa [in Polish].

\section{Борисюк I. O.}

аспірант кафедри педагогіки, початкової освіти та освітнього менеджменту Ніжинського державного університету імені Миколи Гоголя, Україна

\section{Новгородська Ю. Г.}

кандидат педагогічних наук, доцент кафедри педагогіки, початкової освіти та освітнього менеджменту Ніжинського державного університету імені Миколи Гоголя, Україна

\section{Шала A.}

аспірант педагогічної підготовки, Державне вище професійне училище в м. Хелм, Польща 


\section{СИСТЕМА ЦІННОСТЕЙ ВИХОВАННЯ ДОРОСЛИХ}

У статті актуалізовано проблему формування системи цінностей як аксіологічної основи людини. Визначено сутність френомену "цінності"; розкрито основні наукові позиції вітчизняних і зарубіжних учених з приводу досліджуваного френомену. Зроблено аналіз наведеної в науковій літературі термінології з иієї проблематики. Аналізується ієрархія термінальних та інструментальних иінностей сучасної людини.

Авторами здійснено опис чинників, які впливають на фрормування життєвих цінностей. Проаналізовано вплив статі на формування їхньої системи цінностей. Проведено порівняльний аналіз системи цінностей представників різних статей, які навчаються, а також жінок та чоловіків, які не займаються освітою.

Вивчено відмінності у перевагах цінностей між чоловіками та жінками, які здобувають освіту, та представниками різних статей, які не навчаються. Досліджено відмінності в межах однієї статі у перевагах цінностей - між жінками (чоловіками), які отримують освіту, і тими, хто не здобуває освіту.

Ключові слова: цінності, ціннісні орієнтації, ієрархія иінностей, особистість, стать, гендерна різниия.

\section{Borysiuk I.}

Graduate student, of the Department of Pedagogy, Primary Educational and Management Nizhyn Mykola Gogol State University, Ukraine

\section{Novhorodska Y.}

Candidate of Pedagogical Sciences, Associate Professor of the Department of Pedagogy, Primary Educational and Management Nizhyn Mykola Gogol State University, Ukraine

\section{Szala A.}

postgraduate student of pedagogical preparation, State Higher Vocational School in Chełm, Poland

\section{THE SYSTEM OF VALUES OF ADULT EDUCATION}

The article actualizes the problem of forming a system of values as the axiological basis of man. The essence of the phenomenon of "value" is determined; the main scientific positions of domestic and foreign scientists on the studied phenomenon are revealed. An analysis of the terminology given in the scientific literature on this issue is made. The hierarchy of terminal and instrumental values of modern man is analyzed.

The authors describe the factors that influence the formation of life values. The influence of gender on the formation of their value system is analyzed. A comparative analysis of the value system of representatives of different sexes who study, as well as women and men who are not engaged in education

The differences in the preferences of values between men and women who receive education and representatives of different sexes who do not study are studied. Gender differences in the preferences of values between women (men) who receive education and those who do not receive education have been studied.

Key words: values, value orientations, hierarchy of values, personality, sex, gender difference. 